\title{
Language contact phenomena in the language use of speakers of German descent and the significance of their language attitudes
}

\author{
Veronika Ries (Bielefeld)
}

\begin{abstract}
Within the scope of my investigation on language use and language attitudes of People of German Descent from the USSR, I find almost regular different language contact phenomena, such as viel bliny habn=wir gbackt (engl.: 'we cooked lots of pancakes') (cf. Ries 2011). The aim of analysis is to examine both language use with regard to different forms of language contact and the language attitudes of the observed speakers. To be able to analyse both of these aspects and synthesize them, different types of data are required. The research is based on the following two data types: everyday conversations and interviews. In addition, the individual speakers' biography is a key part of the analysis, because it allows one to draw conclusions about language attitudes and use. This qualitative research is based on morphosyntactic and interactional linguistic analysis of authentic spoken data. The data arise from a corpus compiled and edited by myself. My being a member of the examined group allowed me to build up an authentic corpus. The natural language use is analysed from the perspective of different language contact phenomena and potential functions of language alternations. One central issue is: How do speakers use the languages available to them, German and Russian? Structural characteristics such as code switching and discursive motives for these phenomena are discussed as results, together with the socio-cultural background of the individual speaker. Within the scope of this article I present exemplarily the data and results of one speaker.
\end{abstract}

\section{$1 \quad$ Introduction}

\subsection{Preliminaries}

There are many previous studies about the speech community of people of German Descent from Russia from USSR (in the following "Russlanddeutsche"1) and their language use. With regard to aspects such as linguistic integration, linguistic competence and the definition of mother tongue for Russlanddeutsche, I refer to the research of Nina Berend (e. g. 1998), Katharina Meng (e. g.: Meng/Protassova 2003), and Alena Petrova (e. g. 2003). But there are hardly any studies focusing on the connection between language use and language attitudes.

On the one hand, one finds utterances like und:, denn (.) hab=ich ein=paar TAPOČki² gestrickt. (engl.: 'and then (.) I knitted some slippers'). With the exception of the lexeme TAPOČki, this utterance is in German. Given the fact that the speaker refers to a very special kind of slippers, it's not just the filling of a lexical gap, but an extension of the German lexicon by a Russian lexeme in order to make a new differentiation. One can make the following observations about this example:

\footnotetext{
${ }^{1}$ The term Russlanddeutsche is used in this context because there is no established English equivalent.

2 TAPOČki is a Russian lexeme: plural, diminutive. It can be translated as 'slippers'. The speaker refers to a very special kind of slippers she knitted herself.
} 
- first, the use of both languages in the same utterance and

- second, bilingual linguistic behaviour without any markers for uncommon or marked language use.

My examination of the speaker's linguistic behaviour shows that the use of both German and Russian - in the same utterances, conversation etc. - can be the natural and unmarked language use (see Ries 2008).

On the other hand you find declarations like:

- Ja, einfach dass wir waren Deutsche und wir wollten nach Deutschland und das war's. (engl.: 'Yes, just that we were Germans and we wanted to go to Germany and that's it.')

- Ich bin kein Russe. Was hab ich mit den Russen zu tun? (engl.: 'I am no Russian. What have I to do with Russians?')

- Wir mussten Russisch lernen, ob wir wollten oder nicht. Wir mussten leben. (engl.: 'We had to learn Russian whether we wanted to or not. We had to live.')

- Ja, Russisch vergessen wir doch nicht. Die Sprache bleibt. (engl.: 'Yes, we do not forget Russian, nevertheless. The language remains.')

Statements of this kind provide an insight into the attitudes of the speakers towards their languages. These statements indicate that speakers ascribe different roles and meanings to their two languages.

\subsection{Research questions}

This article will address the following points:

- First, it focuses on language contact phenomena and language alternation with regard to conversation.

- Second, it focuses on the analysis of attitudes of the speakers towards the languages German and Russian.

- Third, it synthesizes the results of the analysis of the language use and the analysis of attitudes.

Verbalised as questions, the examination asks:

- What language contact and language use phenomena are observed?

- What language attitudes towards the languages German and Russian do the speakers have?

- Is there a link between language use in everyday conversation and language attitudes?

To be able to answer this complex and extensive question, more data types are needed. The corpus compiled and edited by myself is the groundwork for analysis and holds three different data types:

- everyday conversation

- interviews (not tightly structured, but following a guideline, 'Leitfadeninterview')

- linguistic biographies of the recorded speakers (socio-cultural background of the speakers) 
Based on the assumption that attitudes are related to experiences with the languages, the data type 'linguistic biographies' is very important as an independent type.

\subsection{Theoretical background}

For the analysis of language contact phenomena and language alternation, I refer to the language contact research and the approaches of Carol Myers-Scotton (e. g., her Matrix Language Frame Model, 2006), Michael Clyne (e. g., his term of transference, 2003), Pieter Muysken (e. g., his idea of congruent lexicalization, 2000) and Peter Auer (primarily his conversational approach to code switching, 1984). I apply the research of Nina Berend (above all her study to linguistic integration, 1998) and Katharina Meng (mainly her research on language use within family, 2001; and her study with Ekaterina Protassova on selfcategorization processes, 2003) in addressing the self-categorization and definition of mother tongue by the Russlanddeutsche.

\section{Historical background}

This paragraph offers a brief overview of the historical background of the group of Russlanddeutsche. This historical background is necessary for the comprehension of the linguistic biographies.

The brief overview begins with one of the largest waves of immigration of German settlers to the Russian Empire in 1763. Tsarina Katharine II sought out German Settlers to occupy sparsely populated areas. Changing language policies over time - from the Russian Empire to the USSR - paralleled alternating phases of linguistic stability and instability among the German settlers (see Berend 1998: 8). At some points in time, the languages of the minorities were the lingua franca in the respective villages, while at other points in time they were replaced by Russian. Russification includes the following aspects:

- Russian became the working language and the medium of instruction (see Rosenberg 1997: 26).

- Russian became increasingly the public language and the language of social life.

In contrast, German is restricted use as the family language, and a situation of diglossia arose from this division (see id. 1997: 29). These different phases are called Russification-waves.

Most of the German settlers tried to preserve their mother tongue, German. The use of the German language was associated with many problems such as discrimination, hostilities and official bans on language use (see Dietz/Hilkes 1992: 47). In 1941, German troops attacked the USSR. Because of their nationality, German settlers were under collective suspicion of collaborating with the enemy, the German troops (see Dietz 1995: 31). A strong sense of community and collective identity emerged in the wake of these shared experiences. Consequences of the acts of war were deportations of German settlers: It was a forced displacement with the aim of dispersion of German village communities (see Graßmann 2004: 269; Dietz 1995: 87).

The migration to Germany leads to a reversal of the situation and of languages: German became the official language and Russian the language of the family. Some situations reappear: due to certain divergent attributes between them and the German people in Germany, some Russlanddeutsche felt discriminated against. This overview showed that a collective identity based on shared experience emerged among Russlanddeutsche, but that the experience of the individual also played an important role. 


\section{$3 \quad$ Method (data, corpus)}

The corpus used for the analysis consists of two data types: everyday conversations - more precisely of family conversations including talks at dinner, family reunions and telephone calls - and interviews. Both the conversations and the interviews were audio recorded. The recordings were transcribed for the detailed analysis contained in this qualitative study. The transcriptions follow the conventions of GAT, the "Gesprächsanalytisches Transkriptionssystem" (Selting et al. 1998). The basis of the qualitative research is the morpho-syntactic and interactional linguistic analyses of authentic spoken data. My being a member of the examined group allowed me to record the speakers in a private environment and to build up an authentic corpus. All speakers who were recorded emigrated from the former Soviet Union. Two extended families (children, parents, uncle and aunt, grandparents and so on) were recorded. These two families do not know each other. At the time of recording, the persons were between 6 and 80 years old. A total of around 90 hours of everyday conversations were recorded.

Throughout the analysis I refer to Peter Auer's concept of "conversational code alternation" (1995: 116). Auer interprets bilingual phenomena in their direct conversational environment and sees the phenomena as dependent on their "sequential environment" (id.: 116; see also 2007: 123-124). According to Auer, the sequential environment covers the immediate preceding turn and the subsequent utterances (ibid.). The idea is that a) the bilingual phenomena could be a reaction to the preceding turn and $b$ ) the subsequent turn shows how the speakers interpret the respective utterances (ibid.).

\section{$4 \quad$ Data analysis}

\subsection{Language use}

The language use of the observed speakers is analysed primarily in everyday conversations. In the following section, two different functions of language switches or of the two languages themselves are shown:
a. contextualization
b. structuring

These two functions can be described as discourse phenomena because the observed language alternations show effects on the level of discourse.

\section{a. contextualization}

By using the term context, I refer to the research of Gumperz and Auer. Auer's approach, that context is not static (see Auer 1986: 99), is elementary. In this, Auer draws on Gumperz' approach stating that context is something to which interacting participants can react and that they can produce and form (see id.: 23). Contextualization describes the processes, which make references to elements of background knowledge ("Hintergrundwissen", see id.: 24) by using contextualization cues (see Gumperz 1982: 131). If relevant knowledge, or context, is missing, then it has to be made accessible to the interaction participants by using different signals, such as rhythm, intonation and tempo (see Auer 1984: 99) or code switching (see Gumperz 1982: 131). In monolingual discourses, the functions of code switching as a contextualization cue may be taken over by prosodic cues (see Auer 1995: 123).

It is certain that code alternation signalises contextualization. Within the data analysed in this article, it is important to point out that the languages are divided by their discourse-pragmatic function for further use: One language serves as language-of-interaction and the respective other language serves as language-of-contextualization. 
The use of the second language as the language-of-contextualization provides the possibility to make a speaker's narrative understandable and interpretable by giving additional information via this language.

(a)

01 Ew: viel bliny habn=wir gbackt (..) Hy когда=я большая была.

transliteration: viel bliny haben=wir gbackt (..) nu kogda=â bol'šâa byla.

translation: we cooked many pancakes (..) well, when I was older.

In this conversational sequence, speaker Ew talks about her life at a specific point in time in her village in Kazakhstan.

Before starting the analysis with regard to contextualization, the occurrence of the lexeme bl iny (engl.: 'pancakes') should be addressed. The use of a Russian lexeme within a German utterance is a code switching phenomenon. This Russian lexeme is integrated into the German utterance. It is definitely not a case of a gap in the lexicon, because there is a German equivalent (Pfannkuchen). But it is reasonable to suppose that this appearance is due to its type: denotations of dishes are prevalently transferred in original terms. It is also important to notice that the term used is more frequently used by Ew.

Besides the described code switching phenomenon, you can also observe the use of both languages, German and Russian:

- German is the base language, which is used for the presentation of the main statement: viel bliny habn=wir gbackt

- After the pause you see the shift into the Russian language. So the pause reflects the alternation point.

- The information uttered in Russian is additional: nu kogda=â bol'šaâ byla. Thus, the previous utterance, the main statement in German, receives more context for a better understanding. A sequence beside the main conversation is formed. The particle $n u$ functions as an indicator for the side sequence in which additional explanation is provided.

Russian, at this point, is the other and second language that takes over the function of specifying and adding comment. A split of the two languages is taking place: on the one hand, there is the language-of-interaction, German; on the other hand, there is the language-ofcontextualization, Russian.

Speaker Ew is using both languages by assigning different functions to them, and structures her utterance accordingly. The following example also shows this linguistic behaviour of speaker Ew - both languages are used to structure her utterance.

\section{b. $\quad$ structuring}

In the following conversational sequence, speaker Ew tells her family about a common friend and her work.

(b) 


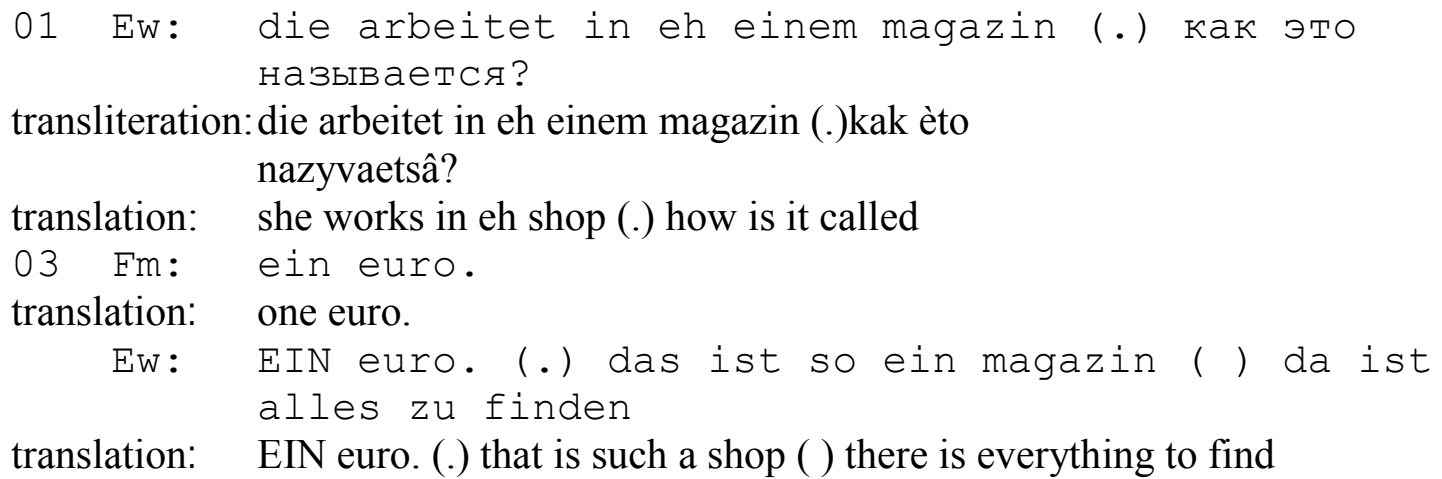

In this situation, several people are at table and Ew describes her friend's job with the help of her husband, Fm. In this sequence, German is the language-of-interaction. Conspicuous is the repeated mention of the lexeme magazin. This apparent Russian lexeme is mentioned twice, and in both cases it is integrated in a German utterance. But it is worthwhile to have a closer look at this lexeme and its use:

The lexeme magazin exists in both lexicons, Russian as well as German. One distinction is the pronunciation. The Russian lexeme is pronounced / $\mathrm{z} /$ and the German lexeme /ts/. Another important distinction concerns the lexicon; namely, that the lexicons show differences and similarities:

- The German lexeme Magazin bears the meaning 'magazine', 'storeroom/repository' and 'ammunition dump at the gun'.

- The Russian lexeme магазин (magazine) bears the meaning 'shop/store' and also 'magazine in firearm'.

In the utterance above, it is definitely used in the sense of a shop, so it matches the Russian lexicon. The lexeme is integrated on the morpho-syntactic level according to the rules of the base language, German (you see the German dative case and not the Russian prepositional case). Another influence takes place in the lexicon: Due to the similarities, a transfer occurs. The result is an extension of the lexicon. My observation of the speaker Ew's language use is that the German lexeme Geschäft (engl.: 'shop') was replaced by the Russian lexeme 'магазин'. With regard to the structural aspect, this phenomenon is reminiscent of the categories loanblends or hybrids in that it shows influences from both languages (see MyersScotton 2006: 224).

The central language contact phenomenon for this analysis is the language switch observed on the level of discourse. There is a language switch from German to Russian and back again. The first switch, from German to Russian, takes place within Ew's turn. The part uttered in Russian includes, inter alia, a new choice in her addressee. In German, the language-ofinteraction, she presents her main information. For a close description of the place of work, speaker Ew wants to name the shop. But she cannot remember the name, and so she turns to her husband Fm. This well-directed turn to her husband occurs in Russian and constitutes a side sequence. In this sequence, speaker Ew is able to work on her request to her husband, separate from the main conversation and without an interruption of her story. It is a kind of self-initiated correction through another participant. The answer of her husband Fm contains just the name of the shop. So it is almost impossible to assign this to a language or to refer to a conscious language choice. After solving the problem, and thus ending the side sequence, Ew carries on with her story in the language-of-interaction. Markers for the side sequence alongside the main conversation are the following: 
- the first pause (line 01) at the point of language switch

- the language switch

- the direct addressee

- label-solving

- the second pause (line 04) at the point of the switch-back

Following this analysis, it is obvious that the lexeme magazin (line 01) does not have the function of a trigger. In particular, the second mention shows that there is no triggering because there is no language switch. It is important that the pause and the language switch occur after the lexeme magazin, and not prior to it.

Both examples show how speaker Ew is using both languages, German and Russian, in order to structure her utterances. There is a wide range of bilingual phenomena, language contact phenomena as transfer, as well as discourse phenomena as a problem-solving sequence.

\subsection{Language attitudes}

In the following section, the data types interviews and linguistic biographies are central. The analysis focuses on the language attitudes of speaker Ew towards the languages German and Russian, and her self-description of her linguistic behaviour.

The first sequence is a short extract from the interview with Ew: she describes her language use in the family domain.

(c)

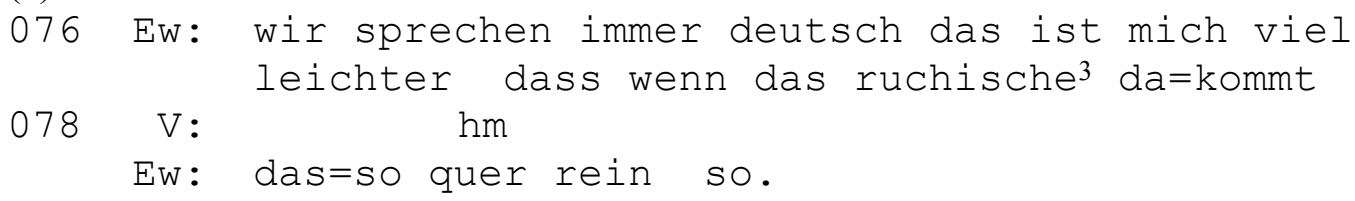

translation: we speaks always German, that is for me much easier, when Russian there comes in so crosswise

This self-description involves two informative and illuminative statements:

1. Right at the beginning, Ew identifies the language use of herself and her husband (referred to with the pronoun wir ('we') as wir sprechen immer deutsch ('we speak always German'). She puts the focus on the German language and the absolute use of it.

2. Within the same utterance, but in the third part, she adds a description of the use of Russian. The conjunction wenn ('if') and the phrasing da=kommt das=so quer rein ('there comes in so crosswise') are crucial because they point out that this last part of her statement is a kind of confession with limitation. She admits that the Russian language is also used, but the use is undesired and bothersome (see quer, 'crosswise'). This proposition is emphasized by the active object of Russian within this statement.

Already in this short extract of the interview with Ew, the meaning of the languages and the respective roles that she ascribes to German and Russian become apparent.

The second sequence shows the extract from the interview where Ew describes a situation between herself and her grandson.

\footnotetext{
3 This is a one-time language slip.
} 
(d)

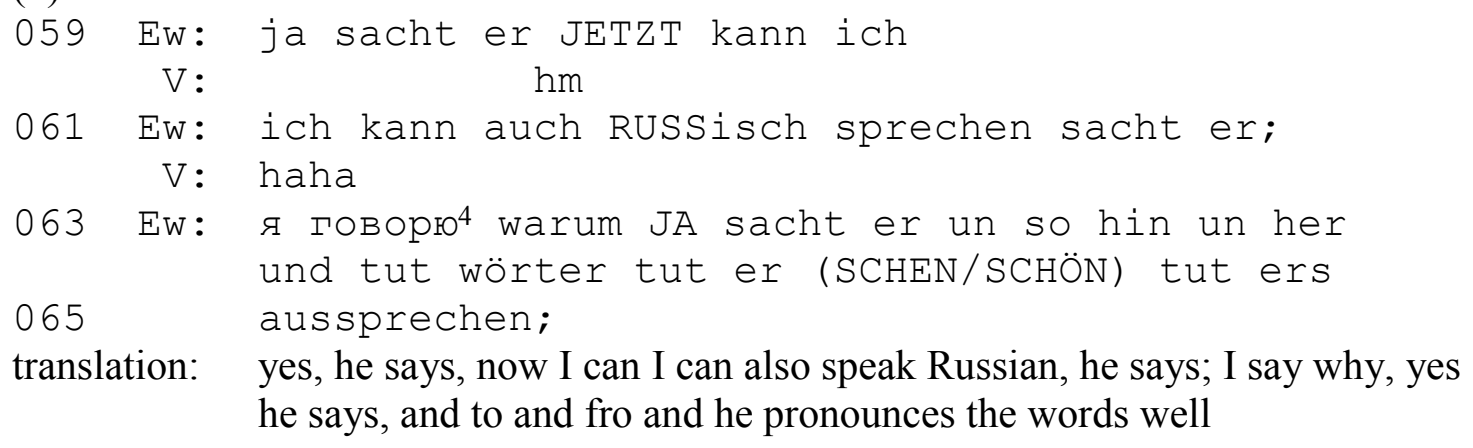

In this fragment two aspects are very important:

- First, the language use of Ew: Speaker Ew does not switch between languages in the entire interview, she speaks German without any language alternations; but in her description of a talk with her grandson she uttered the Russian phrase я говорю (line 063, engl.: 'I say') within her German utterance. This phrase has two functions: a) It marks a quote. b) It structures the utterance. In particular, it marks different speakers in the retell and distinguishes between different times: the narrating time and the actual situation.

This phrase, as a structuring element, is prevalent in her language use irrespective of the language-of-interaction. In addition to its meaning, the phrase $я$ говорю obtains the new function of structuring and develops into a pragmatic marker.

- Second, her language attitudes: Ew says that the pronunciation of the Russian words by her grandson is quite good. This fact points out that Russian and the command of Russian is linked with positive attitudes.

\section{Results and conclusion}

The analysis of the conversation of the data type everyday conversation presents a kind of parallelism of the languages German and Russian: One serves as language-of-interaction and the second language is used flexibly, in the examples for quotations, structuring etc. Thus, an impression arises that the statement is not interrupted, but obtains an additional level through the use of the second language as a structuring aid.

In the third data type linguistic biographies, speaker Ew has two linguistic biographies:

- The first linguistic biography is based on my knowledge because of my acquaintance with the recorded speaker. There were different phases in her life where one language was prevalent - and so there was also a phase of life where the Russian language was the dominant one.

- The second linguistic biography is based on her official declaration as part of the research. She stated that German was and is the dominant language and that Russian had to be learned.

Both biographies are important because it is very meaningful that she changes her biography when providing it for official information.

The analysis of all three types - language use, language attitudes and linguistic biography leads to the following conclusion: Speaker Ew has a certain image of herself that she is

4 â govorû (engl:: 'I say'). 
carrying out. Most probably it is a self-perception she wants to show in opposition to the actual linguistic behaviour of using both languages. In the private domains, Ew uses both languages available to her. For fear of diminishing her German identity, she matches her biography with her attitudes and her self-description of her language use.

\section{References}

Auer, Peter (1984): Bilingual conversation. Amsterdam: Benjamins.

Auer, Peter (1986): "Kontextualisierung". Studium Linguistik 19: 22-47.

Auer, Peter (1995): "The pragmatics of code-switching. A sequential approach". In: Milroy, Lesley/Muysken, Pieter (eds.): One speaker, two languages. Cross-disciplinary perspectives on code-switching. Cambridge: Cambridge University Press: 115-135.

Auer, Peter (2007): "The pragmatics of code-switching. A sequential approach". In: Wei, Li (ed.): The bilingualism reader. London, Routledge: 123-138.

Berend, Nina (1998): Sprachliche Anpassung. Eine soziolinguistisch-dialektologische Untersuchung zum Rußlanddeutschen. Tübingen: Narr.

Clyne, Michael (2003): Dynamics of language contact. English and immigrant languages. Cambridge: Cambridge University Press.

Dietz, Barbara (1995): Zwischen Anpassung und Autonomie. Rußlanddeutsche in der vormaligen Sowjetunion und in der Bundesrepublik Deutschland. Berlin: Duncker \& Humblot.

Dietz, Barbara/Hilkes, Peter (1992): Russlanddeutsche. Unbekannte im Osten. München: Olzog. (= Geschichte und Staat 292).

Graßmann, Walter (2004): Geschichte der evangelisch-lutherischen Rußlanddeutschen in der Sowjetunion, der GUS und in Deutschland in der zweiten Hälfte des 20. Jahrhunderts. Gemeinde, Kirche, Sprache und Tradition. Ludwig-Maximilians-Universität München. Dissertation.

Gumperz, John J. (1982): Discourse strategies. Cambridge: Cambridge University Press.

Meng, Katharina (2001): Russlanddeutsche Sprachbiografien. Untersuchungen zur sprachlichen Integration von Aussiedlerfamilien. Tübingen: Narr.

Meng, Katharina/Protassova, Ekaterina (2003): "Deutsche, Russlanddeutsche, RusseDeutsche, rusaki. Selbstbezeichnungen und Selbstverständnisse nach der Aussiedlung". Osnabrücker Beiträge zur Sprachtheorie 65: 173-202.

Muysken, Pieter (2000): Bilingual speech. A typology of code-mixing. Cambridge et al.: Cambridge University Press.

Myers-Scotton, Carol (2006): Multiple voices. An introduction to bilingualism. Malden, MA: Blackwell.

Petrova, Alena (2003): Zur kulturellen Identität der Russlanddeutschen. Universität Heidelberg. Essay. http://www.ub.uni-heidelberg.de/archiv/4192, accessed September 9, 2009.

Ries, Veronika (2008): Sprachkontaktphänomene in Gesprächen Russlanddeutscher in Deutschland. Detaillierte Analyse an konkreten Sprachbeispielen. University of Bielefeld. Unpublished master thesis.

Ries, Veronika (2011): 'da=kommt das=so quer rein'. Sprachgebrauch und Spracheinstellungen Russlanddeutscher in Deutschland. University of Bielefeld. PhD thesis.

Rosenberg, Peter (1997): "Die Sprache der Deutschen in Russland". In: Stricker, Gerd (ed.): Deutsche Geschichte im Osten Europas. Russland. Berlin, Siedler: 585-608.

Selting, Margret et al. (1998): "Gesprächsanalytisches Transkriptionssystem (GAT)". Linguistische Berichte 173: 91-122. 